\title{
MULTIPLE CONGENITAL COAGULATION DEFICIENCIES
}

\author{
BY \\ J. A. BONNIN, N. D. HICKS, M. D. INNIS, AND D. A. SIMPSON \\ From the Institute of Medical and Veterinary Science, Adelaide, and the Adelaide Children's \\ Hospital, North Adelaide
}

(RECEIVED FOR PUBLICATION MARCH 17, 1960)

\begin{abstract}
A 6-week-old infant is presented who suffered from a congenital haemorrhagic disorder which caused death from subdural haemorrhage following mild trauma. Haematological investigation revealed deficiencies of factor VII and Christmas factor. Prower-Stuart factor was probably also deficient although investigation of this clotting factor was carried out only on serum obtained at necropsy.
\end{abstract}

Multiple congenital deficiencies of coagulation factors occur infrequently and only a small number of such cases have been reported in the literature (Constandoulakis, 1958). The combined deficiencies of factor VII and Christmas factor have been described by several authors (Bell and Alton, 1955; Stein and Abrahams, 1956; de Vries, Kettenborg, and van der Pol, 1955; and Nour-Eldin and Wilkinson, 1959), but none of these investigators has carried out tests to exclude the possibility of an additional deficiency of Prower-Stuart factor. The infant reported in this paper is of interest because all three of these factors are believed to have been deficient. Factor $\mathrm{X}$ has not been considered because Denson (1958) has produced evidence to suggest that it is identical with Prower-Stuart factor. The case is also of some clinical interest as an example of the occasional important relation between traumatic intracranial haemorrhage and coagulation defect. It has already been briefly reported in that connexion (Simpson and Robson, 1960).

\section{Clinical Summary}

A.T.U., aged 6 weeks, a boy, was admitted to the Adelaide Children's Hospital on July 29, 1959. The parents stated that he had been mildly unwell for several days. On the day of admission he had vomited and passed several loose stools. The right face and arm had twitched. He had become progressively more drowsy, and by the time he came into hospital he barely responded to painful stimuli. On particular inquiry, the parents recalled that the baby had received a trivial bump to the head on the previous day. On several occasions they had noticed that the baby developed bruises with undue ease; he had also bled excessively from scratches and from a small infection on the foot.
On examination, he was found to be deeply unconscious. The fontanelle was stony hard. There was an obvious paralysis of the left third nerve; the left pupil was dilated and unreactive, the right pupil reacted sluggishly. The pulse was slow (70-80) and the respiration periodic. A diagnosis of acute subdural haematoma was made, and immediate operation advised.

While preparations were being made, it was noted that the blood clotting time was prolonged. This confirmed the suspicion of a coagulation disorder. The parents, who were intelligent people, knew of no other bleeders among their near relatives; their other child was wholly normal in this respect.

Operation was carried out under general anaesthesia. Burr holes were made in the left frontal and parietal regions. Fluid and solid blood were found in the subdural space under great pressure; it was evacuated without difficulty, but the exact volume could not be measured. A right frontal burr hole disclosed no abnormality. At this stage the child's general state worsened, and it was decided that osteoplastic decompression would not be tolerated.

During operation, fresh frozen plasma $(130 \mathrm{ml}$.) and blood (about $30 \mathrm{ml}$.) were infused, and later more blood was given to a total of perhaps $250 \mathrm{ml}$. When the baby left the theatre, the conscious state had improved, but soon after this he became markedly shocked, and, despite transfusion and the use of vasopressor drugs, he died several hours later. The pre-operative haemoglobin was estimated at $7.0 \mathrm{~g} . \%$. The platelet count, total leucocyte count, and examination of a stained blood smear were all within normal limits.

\section{Necropsy}

The examination was carried out eight hours after death. The body was that of a male infant weighing $4,750 \mathrm{~g}$. with extreme pallor of the skin and mucous membranes. There were four or five bruises situated on both knees, the sternum, and the right side of the scalp. 
Three surgical incisions were present on the scalp and blood oozed from these wounds although they were firmly sutured. A scratch mark with a well-formed scab was present on the right cheek and there was a drip incision over the left medial malleolus. The right great toe nail had a little clotted blood under one margin. The diaphragm was at the level of the sixth rib on the left and the fifth rib on the right side. The liver weighed $166 \mathrm{~g}$., was soft, mottled, brownish-red, and on incision was yellowish-brown and moist. The spleen was purple, weighed $15 \mathrm{~g}$., and the Malpighian bodies were visible. The heart was pale and the chambers contained an unusually small amount of blood. Burr holes were present on either side of the frontal bone and another was situated over the left parietal bone. A subdural blood clot approximately $5 \mathrm{~cm} . \times 3 \mathrm{~cm} . \times 0.3 \mathrm{~cm}$. was situated over the left cerebral hemisphere. Underlying this was a subarachnoid film of blood. On incision an area of softening, approximately $3 \mathrm{~cm}$. in diameter, was seen in the parietal lobe extending from the posterior central gyrus to the angular gyrus. In the right cerebral hemisphere there was a thin subarachnoidal film of blood covering the parietal lobe. A localized widening of the central sulcus was evident and on incision two small haemorrhagic areas about $5 \mathrm{~mm}$. in diameter were present in the putamen. The leptomeninges covering the vermis and left lobe of the cerebellum were discoloured a dark orange. Pallor of the trachea was marked. No other naked-eye abnormality was seen.

Histological examination of the liver showed an occasional very early micro-abscess with an excess of leucocytes in the sinusoids. Leucocytes were excessive in the splenic sinusoids. The bone marrow showed megakaryocytic hyperplasia. In the brain, subarachnoid and intracerebral haemorrhages were evident, with necrosis and softening of the adjacent brain tissue.

\section{Investigation of the Coagulation Abnormality}

Materials and Methods.-A small amount of blood was obtained from a cannula passed directly into an arm vein which was exposed before transfusion. Approximately $1 \mathrm{ml}$. was placed in a sterile bottle and allowed to clot at room temperature. Serum was separated after storage overnight at $37^{\circ} \mathrm{C}$. The remainder of the blood obtained was mixed with one-ninth volume of $3.8 \%$ sodium citrate solution and the plasma was separated by centrifugation at 3,000 r.p.m. for 10 minutes.

Plasma deficient in factor VII was obtained from the patient previously reported in detail (Hicks, 1955) who suffered from a congenital deficiency of this factor. The plasma was stored at $-20^{\circ} \mathrm{C}$. before use. Serum from a patient with Christmas disease was stored similarly. Dindevan plasma was collected from a patient who had been treated with this drug for three weeks. $\mathrm{Al}(\mathrm{OH})_{3^{-}}$ treated plasma was obtained by mixing fresh plasma with one-ninth volume of $\mathrm{Al}(\mathrm{OH})_{3}$-gel and agitating at $37^{\circ} \mathrm{C}$. for four minutes before separation by centrifugation.

The one-stage prothrombin test of Quick (1935) was carried out using a $5 \%$ suspension of acetone-treated human brain.

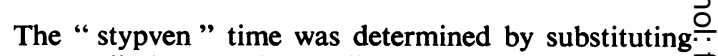
"stypven" (Burroughs Wellcome \& Co.), to which lipoid had been added, for the brain extract in the one- $\frac{\text { ? }}{-}$ stage prothrombin test.

The two-stage prothrombin test (Biggs and Douglas, $\frac{\bar{\sigma}}{\bar{n}}$ 1953a) was modified as described by Hicks (1955), and $\frac{\bar{s}}{\sigma}$ in addition an equal volume of serum was added to supply adequate quantities of factor VII and ProwerStuart factor.

The thromboplastin generation test and the thrombo- $\overrightarrow{0}$ plastin generation screening test were carried out as $\overrightarrow{-}$ described by Biggs and Douglas (1953b) and Hicks andw Pitney (1957) respectively.

\section{Results}

Whole-blood Clotting Time.-Blood collected as $\stackrel{\vec{\omega}}{+}$ described above took a little longer than one hour $\overrightarrow{+}$ to coagulate. The clot which formed was firm, of $\vec{\circ}$ normal consistency, and retracted well without any? appreciable fibrinolysis.

Quick's One-stage Prothrombin Test. - The patient's plasma showed a markedly prolonged $\vec{\bullet}$ clotting time when tested by Quick's method. Mixing experiments were carried out as shown in Table I. The defect in the patient's plasma was almost corrected by the addition of $20 \%$ of normal

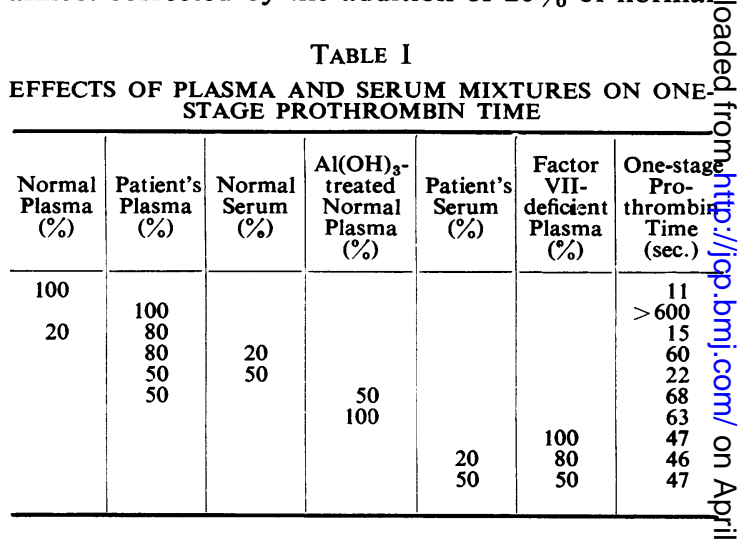

plasma. It was improved by adding $50 \%$ of normabs serum, but $\mathrm{Al}(\mathrm{OH})_{3}$-treated plasma had no effect $N$ The patient's serum did not improve the prolonged one-stage time of factor-VII-deficient plasma.

Thromboplastin Generation Studies.-A grosહ defect in the patient's plasma was demonstrated by the thromboplastin generation screening test $\stackrel{+}{+}$ Mixing experiments were therefore carried out aso shown in Table II. It can be seen that normal serum? corrected the defect, but even when as much as $20 \%$ of undiluted $\mathrm{Al}(\mathrm{OH})_{3}$-treated normal plasma was added to the incubation mixture, little or no improvement occurred. Factor-VII-deficient plasma also corrected the abnormality, but serum deficieng 
TABLE II

EFFECTS OF ADDED PLASMA OR SERUM ON THROMBOPLASTIN GENERATION SCREENING TEST

\begin{tabular}{|c|c|c|c|c|c|c|c|}
\hline $\begin{array}{c}\text { Normal } \\
\text { Plasma } \\
\text { Diluted } \\
1 / 10 \\
(\%)\end{array}$ & $\begin{array}{c}\text { Patient's } \\
\text { Plasma } \\
\text { Diluted } \\
1 / 10 \\
(\%)\end{array}$ & $\begin{array}{c}\text { Normal } \\
\text { Serum } \\
\text { Undiluted }\end{array}$ & $\begin{array}{c}\text { Normal } \\
\text { Serum } \\
\text { Diluted } \\
1 / 10 \\
(\%)\end{array}$ & $\begin{array}{c}\mathrm{Al}(\mathrm{OH})_{3} \text {-treated } \\
\text { Normal } \\
\text { Plasma } \\
\text { Undiluted } \\
(\%)\end{array}$ & $\begin{array}{c}\text { Factor VII- } \\
\text { deficient } \\
\text { Plasma } \\
\text { Diluted 1/10 } \\
(\%)\end{array}$ & $\begin{array}{l}\text { Christmas-factor- } \\
\text { deficient } \\
\text { Serum } \\
\text { Diluted 1/10 } \\
(\%)\end{array}$ & $\begin{array}{l}\text { Screening Test: } \\
\text { Minimum Clotting } \\
\text { Time (sec.) of } \\
\text { Six Successive } \\
\text { Min. Subsamples }\end{array}$ \\
\hline 100 & $\begin{array}{r}100 \\
80 \\
80\end{array}$ & 20 & & 20 & & & $\begin{array}{l}9 \frac{1}{2} \\
70 \\
10 \frac{1}{2} \\
35\end{array}$ \\
\hline \multicolumn{8}{|c|}{ Tests carried out after storage at $-20^{\circ} \mathrm{C}$. } \\
\hline 100 & $\begin{array}{r}100 \\
80 \\
50 \\
50 \\
50\end{array}$ & & $\begin{array}{l}20 \\
50\end{array}$ & & 50 & 50 & $\begin{array}{l}10 \frac{1}{2} \\
40 \\
15 \\
12 \\
12 \frac{1}{2} \\
28\end{array}$ \\
\hline
\end{tabular}

in Christmas factor had little beneficial effect. Similar results were also obtained with the thromboplastin generation test of Biggs and Douglas (1953b). However, insufficient plasma was available for treatment with $\mathrm{Al}(\mathrm{OH})_{3}$-gel and experiments were therefore carried out on the patient's serum only, in the presence of normal $\mathrm{Al}(\mathrm{OH})_{3}$-treated plasma and lipoid platelet substitute. The defect did not appear as pronounced with this test as in the thromboplastin generation screening test. A minimum substrate clotting time of 16 seconds was obtained when the patient's serum was examined.

Two-stage Prothrombin Test.-Prothrombin was found to be present in adequate quantities. The areas enclosed by the curves in Fig. 1 are proportional to the amounts of prothrombin in the patient's plasma and in plasma from a normal subject.

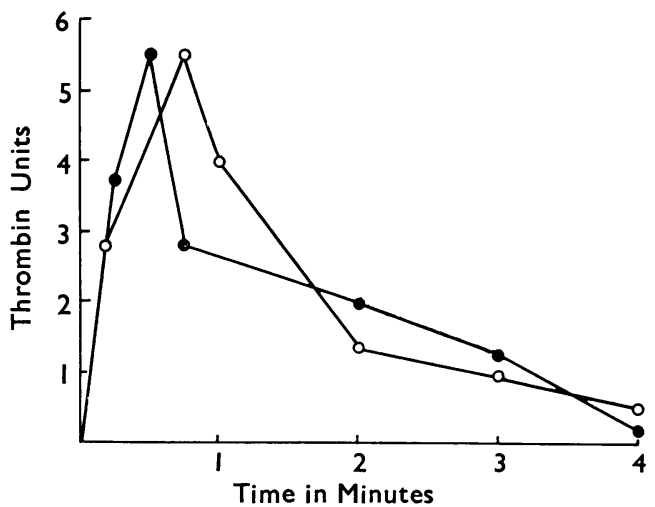

FIG. 1.-The two-stage prothrombin test was performed on normal plasma (-O) and a plasma from the patient $(\mathrm{O}-\mathrm{O})$. An equal volume of serum was added to supply adequate quantities of factor VII and Prower-Stuart factor.

Stypven Clotting Time.-At this stage of the investigation no plasma or serum taken from the patient before death remained and these tests were carried out using serum obtained from the right ventricle at necropsy eight hours after death. The results are tabulated in Table III, which shows that the addition of the patient's serum did not appreciably shorten the "stypven" time of the "dindevan " plasma.

TABLE III

EFFECT OF PATIENT'S SERUM ON VIPER VENOM TIME OF DINDEVAN PLASMA

\begin{tabular}{c|c|c|c}
\hline $\begin{array}{c}\text { Normal } \\
\text { Plasma } \\
(\%)\end{array}$ & $\begin{array}{c}\text { Dindevan } \\
\text { Plasma } \\
(\%)\end{array}$ & $\begin{array}{c}\text { Patient's } \\
\text { Serum } \\
(\%)\end{array}$ & $\begin{array}{c}\text { Russell's Viper } \\
\text { Venom Time } \\
(\text { (sec.) }\end{array}$ \\
\hline 100 & 100 & & $10 \frac{1}{2}$ \\
& 80 & 20 & $25 \frac{1}{2}$ \\
& 50 & 50 & $22 \frac{1}{2}$ \\
\hline
\end{tabular}

\section{Discussion}

The investigation of this patient was hampered by the very small amount of blood available for testing. Approximately $1 \mathrm{ml}$. of plasma and $0.5 \mathrm{ml}$. of serum were obtained. The number of tests carried out was therefore limited to those considered most essential for the determination of the disorders present.

The one-stage prothrombin test revealed a striking abnormality. The results of the mixing experiments shown in Table I indicate that normal serum contained a factor (or factors) capable of considerably improving the defect. Factor VII and ProwerStuart factor are present in normal serum and are concerned in the reaction between plasma and tissue thromboplastin. Therefore, a deficiency of either or both of these factors could have been responsible for the patient's prolonged one-stage clotting time. A deficiency of factor VII was shown conclusively when the patient's serum and a plasma sample known to be deficient in factor VII only were not mutually corrective. The viper venom time is prolonged with plasma deficient in Prower-Stuart factor but remains normal when factor VII is absent. 
Dindevan plasma was used as a source of plasma deficient in Prower-Stuart factor, and the fact that this and the patient's serum were not mutually corrective for the viper venom time (Table III) suggests that the patient was deficient also in ProwerStuart factor. It was unfortunate that there was insufficient patient's plasma to estimate the viper venom time directly, and that the serum used had to be obtained after death. It is difficult to be certain of the reliability of work carried out on serum obtained after death, although three other sera similarly obtained at necropsy contained adequate amounts of Prower-Stuart factor. This suggests that the absence of this factor from the patient's serum was not due to post-mortem deterioration, and transfusion during life had not raised the levels to normal values.

Normal plasma was found to have a more pronounced effect than normal serum in correcting the prolonged one-stage time in Table $I$. It was felt that this indicated an additional deficiency of a factor normally present in plasma but not in serum. However, the two-stage prothrombin test (Fig. 1) revealed normal amounts of prothrombin, and mixing experiments involving $\mathrm{Al}(\mathrm{OH})_{3}$-treated normal plasma (Tables I and II) failed to demonstrate any deficiency of factor $V$. We can therefore offer no satisfactory explanation of this phenomenon. The pattern of results was not consistent with the presence of an anticoagulant substance nor with any appreciable degree of fibrinogen deficiency.

Thromboplastin generation studies provided evidence of a further clotting factor deficiency. The results shown in Table II indicate that normal serum contained a factor (or factors) which corrected thes patient's defective thromboplastin generation and which was not present in normal plasma aftex absorption with $\mathrm{Al}(\mathrm{OH})_{3}$-gel. This finding could therefore have been due to the probable deficiency of Prower-Stuart factor or to an additional defie ciency of Christmas factor. A deficiency of the latter? was demonstrated by the failure of serum from $a$ case of Christmas disease to correct the defect. It $\vec{t}$ was noted that factor-VII-deficient plasma correcteक the thromboplastic abnormality in the patient's plasma, but this was to be expected because factor. VII is not concerned in thromboplastin generation

A similar but less severe disorder is sometimes associated with liver disease, but the changes found in the liver of this patient were not sufficient tog cause a serious dysfunction. The age of the infant was inconsistent with a diagnosis of haemorrhagic disease of the newborn.

We wish to thank Dr. E. B. Sims and the boar\& of management of the Adelaide Children's HospitaP for permission to publish this case report.

\section{REFERENCES}

Bell, W. N., and Alton, H. G. (1955). Brit. med. J., 1, 330. Biggs, R., and Douglas, A. S. (1953a). J. clin. Path., 6, 15. C- (1953b). Ibid., 6, 23.

Constandoulakis, M. (1958). Ibid., 11, 412.

Dawson, K. W., (1958). Brit. J. Haematol., 4, 313.

Hicks, N. D. (1955). Med. J. Aust., 2, 331 . and Pitney, W. R. (1957). Brit. J. Haemat., 3, 227.

Nour-Eldin, F., and Wilkinson, J. F. (1959). Lancet, 1, 1173.

Quick, A. J. (1935). J. biol. Chem., 109, lxxiii.

Simpson, D. A., and Robson, H. N. (1960). Aust. N.Z. J. Surg年

Stein, H. B., and Abrahams, O. L. (1956). S. Afr. J. med. Sci., 21, 13

Vries, S. I. de, Kettenborg, H. K., and Pol, E. T. van der (1955) Acta haemat. (Basel), 14, 43. 